\author{
Military Technical College \\ Kobry Elkobbah, Cairo, \\ Egypt.
}

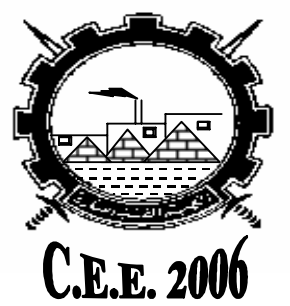

$3^{\text {rd }}$ International Conference

On

Chemical \& Environmental

Engineering

\title{
REMOVAL OF MALATHION CONTAMINATION FROM WATER: EXTRACTION CONDITIONS
}

\author{
Awaad M. I. *, Haridi M. T. * and Elsaiid A. E. *.
}

\begin{abstract}
Malathion (O,O dimethyl phosphorodithioate of diethyl mercaptosuccinate) is one of the most world widely used as a non-systemic pesticide. Water contamination by malathion is problematic in factories, stores and end user sites. Seven of the most common non-polar solvents have been tested as water decontaminating agents. Stock solution containing $145 \mathrm{mg}$ Malathion per liter of deionized water was prepared.50 ml samples were mixed with known volumes of the selected extracting agent. The mixture was then stirred for a prescribed time interval at a fixed temperature. The phases were then separated and analyzed using a high performance liquid chromatograph. The extraction efficiency was calculated, and effect of each of the operating parameters on its value was determined. Benzene was found to be the most efficient extracting agent. The favorable mode of extraction and operating conditions are presented.
\end{abstract}

\section{KEY WORDS}

Water pollution, Malathion, and Solvent extraction.

\footnotetext{
* Egyptian Armed Force.
} 


\section{INTRODUCTION.}

Water pollution is the contamination of fresh or saline water with materials, which are toxic, or otherwise harmful to human beings. The liquid wastewater is essentially the water supply of the community after it has been fouled by a variety of uses. If this wastewater is allowed to accumulate, decomposition of the organic contaminants may lead to production of large quantities of the malodorous gases. [1-2].

The large-scale application of pesticides and insecticides in agriculture and forest areas can contribute to the presence of these toxic materials in the surface ground water and ultimately in water supplies. Contamination can also occur through draining from surrounding terrain, precipitation from atmosphere or accident spills of pesticides in the watershed area [3].

Malathion is a typical example of the non-systemic, wide spectrum organophosphate insecticides [4-5]. It is usually applied in million pound quantities worldwide annually because of its potent insecticide activity and relatively low mammalian toxicity [6]. Malathion's main biochemical action is on the nerve system. It acts as acetyl cholinesterase inhibitor, as are the most organophosphorous compounds [7].

A number of techniques are available for removal and/or recovery of the organophosphorous insecticides from wastewater. Solvent extraction is one of these techniques, which based on the relative solubility of an analyte in two immiscible liquids. [8-9].

\section{EXPERIMENTAL}

\section{Chemicals.}

The used chemicals are all of the HPLC grade as given in Table 1. Deionised water was used for preparation of the standard solutions and the eluenting agents.

Table 2.provides information about structures, grades, physical properties, and the suppliers of the employed malathion.

\section{Instrumentation and Operating Conditions}

Organophosphorous pesticides show normally typical absorption bands in the UV-Vis region, hence UV detectors were suitable for the performed chromatographic analysis.

Absorbance of malathion in UV-Vis region was measured by a Shimadzue UV-Vis double beam spectrophotometer model 1700. 
An Agilent 1100 series HPLC was employed for analyzing the contaminated samples before and after extraction

The following operating conditions were adopted:

- Stationary phase: $150 \mathrm{~mm}$ * $10 \mathrm{~mm}$ ld reversed phase column Zorbax SB C-18.

- Mobile Phase: $\quad$ ACN (30\%) - Water (70\%).

- Flow rate: $\quad 0.3 \mathrm{ml} / \mathrm{min}$.

- Injection volume: $3 \mu \mathrm{l}$.

- Detector: UV Detector at $300 \mathrm{~nm}$.

- Post run: 30 minute.

- Column temperature: $37^{\circ} \mathrm{C}$

- External standard method (EST) was employed

The stock solution of malathion was prepared by dissolving $145 \mathrm{mg}$ of malathion in deionized water and completing to $1000 \mathrm{ml}$.

The calibration curve given in Fig. 3. was obtained via successive dilution of the mentioned stock solution.

\section{Extraction of Malathion}

Batchwise extraction was employed for removal of malathion from the artificially contaminated water samples, $50 \mathrm{ml}$ of the polluted sample was placed in a $250 \mathrm{ml}$ Erlenmeyer flask. $6 \mathrm{ml}$ of the selected solvent were then added, the extraction time was selected from 1 to 20 minutes depending upon the temperature during extraction. Magnetic stirrer was employed to accelerate the extraction process. Separation of the phases was done by a bench top centrifuge.

Effects of the solvent type, solvent quantity, extraction time and temperature were investigated.

\section{RESULTS AND DISCUSSION}

The maximum absorbance of malathion in the UV-visible region was found to be $330 \mathrm{~nm}$.

\section{Effect of the Solvent Type}

Fig. 1, shows that benzene is suitable solvent for extracting malathion from water. the extraction efficiency of xylene contrarily was very low. 


\section{Effect of the Solvent Quantity.}

Fig. 2. shows the relationship between the solvent volume and the residual concentration of malathion in (ppm). As the amount of benzene increases, the residual concentration of malathion decreases and consequently the efficiency of extraction increases.

The minimum amount of benzene required for complete extraction of malathion contaminating $50 \mathrm{ml}$ water sample was found to be $6 \mathrm{ml}$. This means that benzene can remove malathion from contaminated water which is eight times larger in volume.

\section{Effect of Extraction Time}

Fig. 3, shows the relationship between the extraction time in minutes and the residual concentration of malathion in ppm. As the stirring time increases, the residual concentration of malathion decreases and consequently the efficiency of extraction increases.

The minimum time required for complete extraction of malathion from contaminated water was found to be 6 minutes. These values express the rapidity of decontamination and consequently its economic feasibility.

\section{Effect of Temperature on the Extraction Process.}

Fig. 4, shows the relationship between the solvent amount in $\mathrm{ml}$ and the residual concentration of malathion at different temperatures. As the temperature increases the amount of solvent required for extraction slightly decreases and consequently the efficiency of extraction increases. The normal temperature can therfore be adopted regarding the effeciency and economy of the carried out extraction process.

Fig.5 shows the relationship between the extraction time in minutes and the residual concentration of malathion at different temperatures. As the temperature increases, the time required for extraction slightly decreases consequently, the efficiency of extraction slightly increases.

But once more the normal temperature can be adopted for rationalizing the energy consumption without losing much of the extraction efficiency. 


\section{CONCLUSION}

- Benzene was found to be the most efficient solvent compared with the other selected ones.

- One milliliter of benzene was found to be capable of decontaminating completely about eight milliliters of the contaminated water (145 ppm).

- The extraction was rapid even at the normal temperature.

- Few minutes were found to be enough for extraction of malathion.

\section{REFERENCES}

[1] N. L. Nemerow, "Industrial Water Pollution; Origin, Characteristics, and Treatment" , Addison. Wesely publishing company, 1987.

[2] R. Johnson," Marine Pollution" Academic press, 1976.

[3] W. J. Hayes, "Pesticides Studied in Man" William \& Wilkins, Baltimore, London 1982.

[4] TSS. Dikshith, Pesticides, in Pesticides of Toxicology in Animals. TSS Dikshith (ed). CRC Press, Boca Raton, FL. pp. 1-41, 1991

[5] USEPA: Office of Pesticide Programs. 2000. Overview of malathion Risk Assessment. http://www.epa.gov/pesticides/op/malathion/overview.htm.

[6] KE. Rodgers, and DD Ellefson. The Mechanism of Modulation of Murine Peritoneal Cell Dysfunction and Mast Cell Degranulation by Low Doses of Malathion. Agents Actions. 35: 57-63. 1992.

[7] H. Chambers, Organophosphorus Compounds: An Overview, in Organophosphates: Chemistry, Fate and Effects. JE Chambers and PE Levi (eds). Academic Press, NY. pp. 3- 17, 1992.

[8] Schroeder D. Edward "Water and Wastewater Treatment " International Student Edition, McGraw - Hill, 1988

[9] L.T. Taylor, Supercritical Fluid Extraction. New York, John Wiley and Sons, Inc., 1996. 


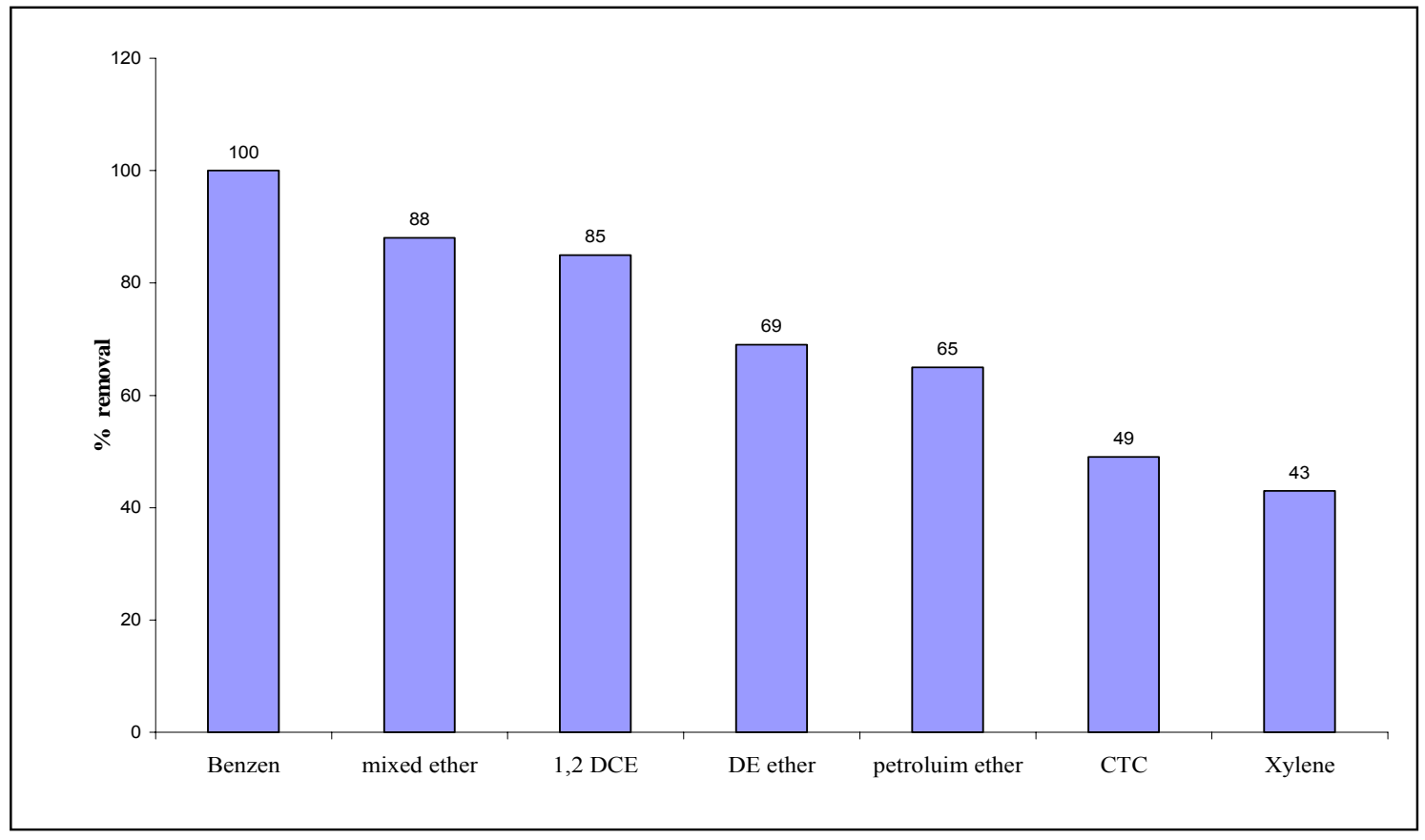

Fig.1. Variation of degree of removal of malathion with the solvent type

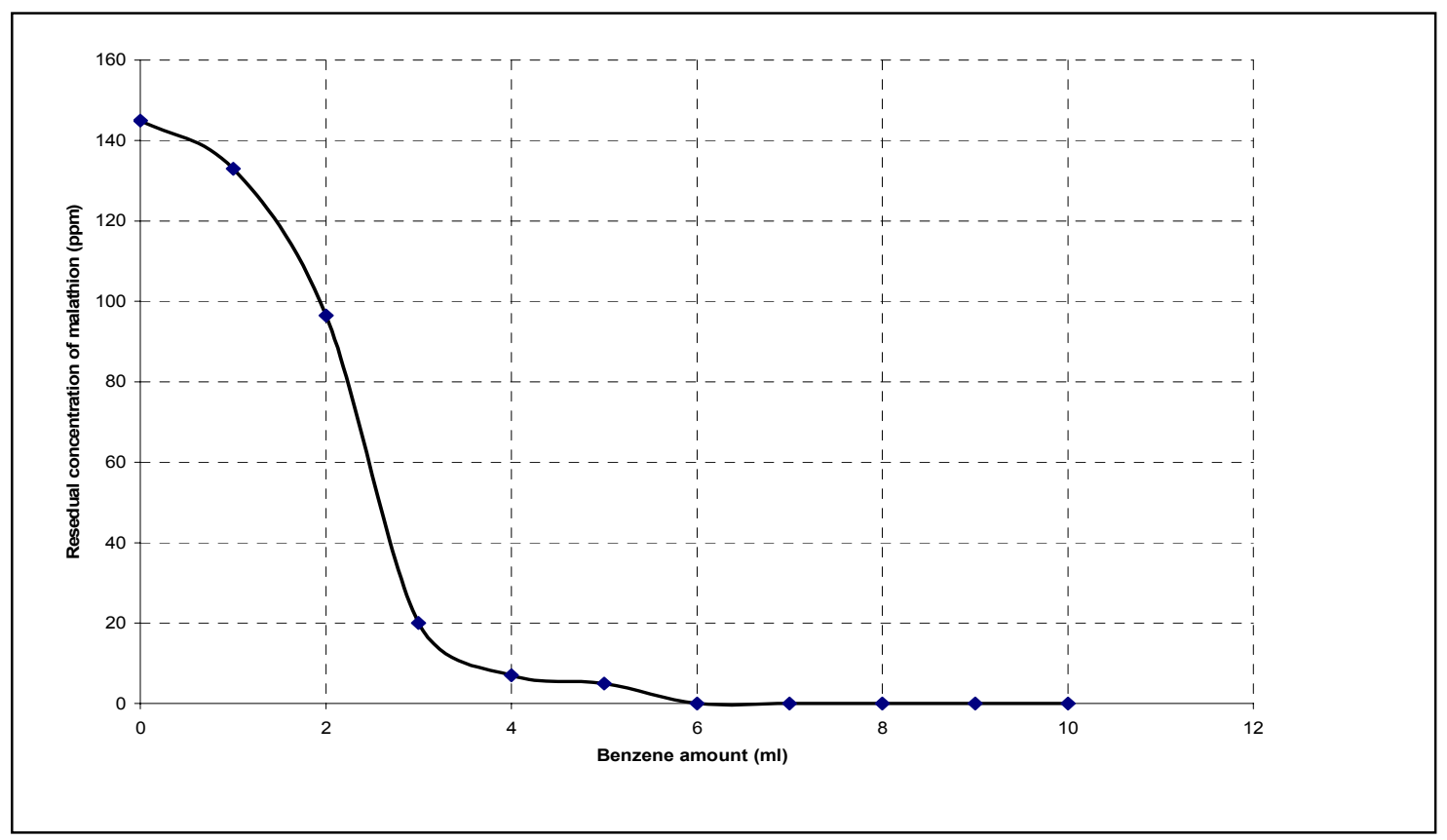

Fig.2 Variation of residual concentration of malathion with the benzene volume 
35

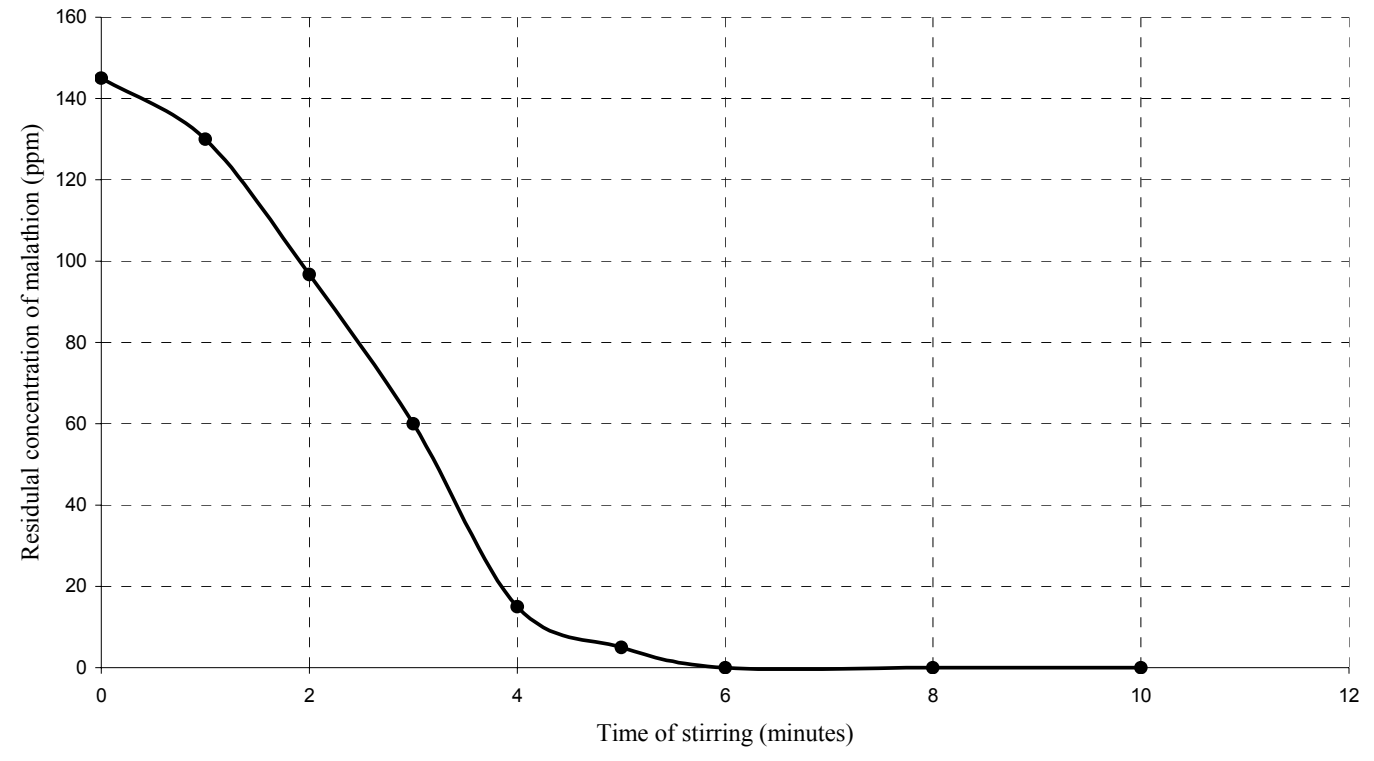

Fig.3. Variation of residual concentration of malathion with the stirring time

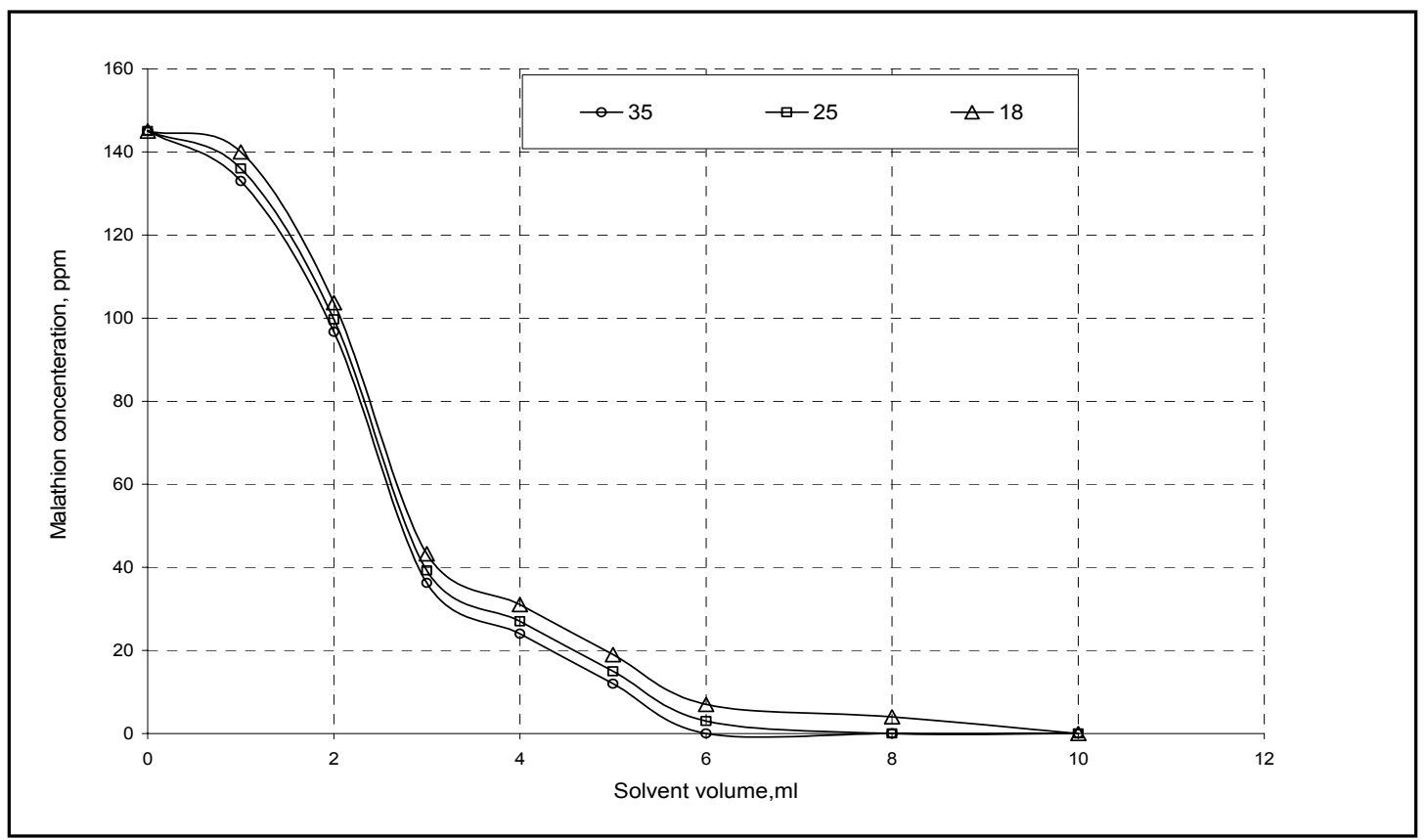

Fig.4. Variation of residual concentration of malathion with the benzene volume at different temperature 


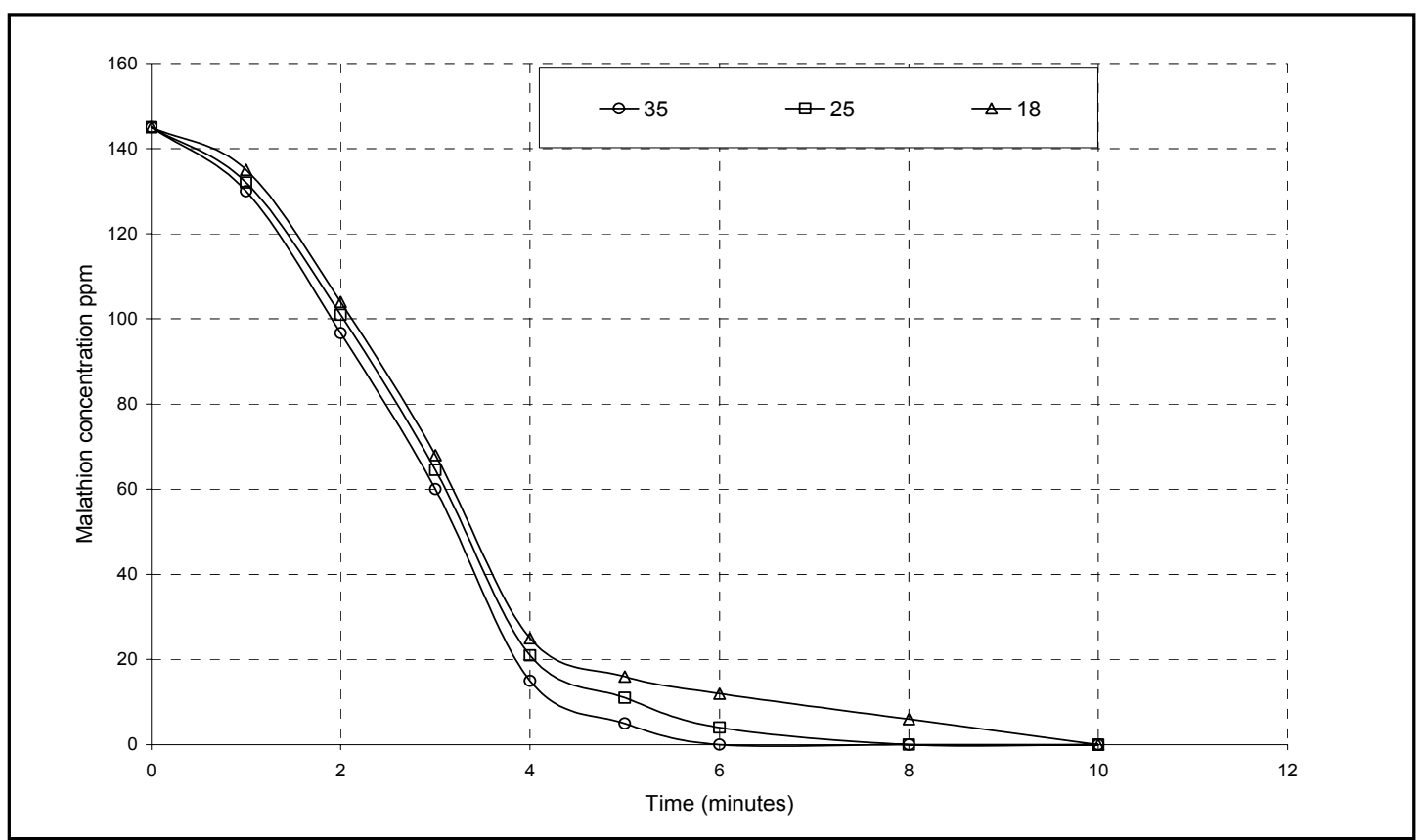

Fig.5. Variation of residual concentration of malathion with the stirring at different temperature. 
Table (1) The Chemicals Used in Analytical Techniques

\begin{tabular}{|c|c|c|c|c|c||}
\hline No. & Chemicals & Chemical formula & symbols & Grade & supplier \\
\hline \hline 1 & Deionized water & $\mathrm{H}_{2} \mathrm{O}$ & DI & HPLC & Fulka \\
\hline 2 & Benzene & $\mathrm{C}_{6} \mathrm{H}_{6}$ & B & HPLC & Fulka \\
\hline 3 & Diethyl ether & $\mathrm{C}_{2} \mathrm{H}_{5}-\mathrm{O}-\mathrm{C}_{2} \mathrm{H}_{5}$ & DEE & HPLC & Aldrich \\
\hline 4 & Carbon tetrachloride & $\mathrm{C}^{-} \mathrm{Cl}_{4}$ & CTC & HPLC & Aldrich \\
\hline 5 & Acetonitrile & $\mathrm{CH}_{3} \mathrm{CN}$ & AcN & HPLC & Aldrich \\
\hline 6 & Toluene & $\mathrm{CH}_{3}-\mathrm{C}_{6} \mathrm{H}_{5}$ & T & HPLC & Riede - Dettaen \\
\hline 7 & Petroleum ether & $\mathrm{Benzin}_{2}$ ether, & PE & HPLC & Honil \\
\hline 8 & Xylene & $\mathrm{CH}_{3}-\mathrm{C}_{6} \mathrm{H}_{4}-\mathrm{CH}$ & X & HPLC & Aldrich \\
\hline 9 & 1,2 dichloroethane & $\mathrm{Cl}_{3}-\mathrm{CH}_{2}-\mathrm{CH}_{2} \mathrm{Cl}$ & $1,2 \mathrm{DCE}$ & HPLC & Aldrich \\
\hline \hline
\end{tabular}

Table (2) Properties of Malathion

\begin{tabular}{|c|c||c|c|}
\hline Chemical formula & $\mathrm{C}_{10} \mathrm{H}_{19} \mathrm{O}_{6} \mathrm{PS}_{2}$ & Melting point ${ }^{\circ} \mathrm{C}$ & 2.9 \\
\hline Solubility in water at $20^{\circ} \mathrm{C}$ & $145 \mathrm{mg} / \mathrm{l}$ & Boiling point ${ }^{\circ} \mathrm{C}$ & 156 \\
\hline Solubility in organic solvents & very soluble & Flash point ${ }^{\circ} \mathrm{C}$ & $>163$ \\
\hline Molecular weight & 330.36 & Specific Gravity at $25^{\circ} \mathrm{C}$ & 1.23 \\
\hline Vapour pressure at $30{ }^{\circ} \mathrm{C}$ & $5.3 \mathrm{mPa}$ & Grade & $95 \%$ \\
\hline Octanol:Water partition coefficient & 2.89 & Source & $\mathrm{NClC}$ \\
\hline \hline
\end{tabular}

